Asst. prof. Bisera Kostadinovska-Stojčevska, PhD.

Original scientific paper

Faculty of Education-Bitola

UDC: 37.037

University “St. Kliment Ohridski”, North Macedonia

Prof. Ljupčo Kevereski, PhD.

Faculty of Education, University "St. Kliment Ohridski"

Bitola, North Macedonia

\title{
CONTEMPORARY CONCEPTS OF EXCEPTIONAL GIFTEDNESS AND ITS DEVELOPMENT: A WAY TO HARMONIZE SOCIAL PERCEPTIONS, AND ENHANCE INSTITUTIONAL TREATMENT AND SELF-PERCEPTION
}

\begin{abstract}
Summary: If we view the civilizational development through the prism of the socio-historical continuum, it seems that we must agree with the claim that the gifted and talented are the creators of the general development of civilizations. This trend continues today, when it is claimed that in the next 20 years, the talented and gifted will inevitably be the most important asset in every institution, especially in contemporary companies. Most of these individuals are believed to perform cognitive tasks at higher mental levels, in which metacognitive thinking that is dominant. This thinking forms a special mental structure, recognizable in such individuals. This paper operates under the assumption that, there is no clearcut picture of the psychological profile of the exceptionally talented with their awe-inspiring performances of their extraordinary abilities which impress the world. Their impressive and fascinating achievements in one or more areas of human life motivate them to be more involved in the world of today. Hence, papers that deal with both theoretical and empirical findings often face a variety of dilemmas and problems regarding the demystification of the psychological code of the exceptionally talented in various scientific and artistic fields. The focus of this paper are the talented and the factors which determine their "superhuman achievements". This paper strives to identify the psycho-physical features of the exceptionally talented and their noteworthy performance in various fields performance that is often referred to as exceptional or expert-like. The aim is to identify the different traits that exceptionally talented individuals working in different fields and arts (science, sports, music, etc.) have. The paper uses the meta-analysis of documentation method, which enables an objective insight into the most significant performances of the exceptionally talented. The results obtained through this method show that the exceptionally talented show a clear, distinctive psychological pattern or. The results obtained reflect a recognizable psychological cod which is unique and specific to those at the pedestal of great achievements. The results will be especially useful for the harmonization of the social view of talent and for the institutional treatment of the talented individuals. Finally, it will improve the talented individuals' self-perception which will positively impact their self-perception which is of great importance for their further educational, psychological and social perception.
\end{abstract}

Keywords: the talented, exceptional results, psychological cod, self-perception. 


\section{SAVREMENA SHVATANJA RAZVOJA VRHUNSKIH TALENATA: KORISNA ZA HARMONIZACIJU DRUŠTVENE PERCEPCIJE, INSTITUCIONALNI TRETMAN I SAMOPERCEPCIONU SLIKU}

Rezime: Ako razvoj civilizacije posmatramo kroz društveno-istorijski kontinuum, čini se da se moramo složiti sa afirmativnom tvrdnjom da su daroviti i talentovani kreatori opšteg razvoja civilizacije. Ovaj trend se nastavlja i danas kada se tvrdi da je sasvim izvesno da će u narednih 20 godina najvažniji resurs u svakoj instituciji, posebno u kompanijama, biti „talenti”. Tvrdi se da većina njih kognitivno funkcioniše na višim mentalnim nivoima, gde dominira metakognitivno mišljenje, formirajući tako karakterističnu mentalnu strukturu. $U$ radu se polazi od pretpostavke da, s obzirom na dosadašnju složenu organizaciju osobina i karakteristika, ne postoji jasna slika o psihološkom profilu talenata sa najmoćnijim iskustvom i performansama svojih sposobnosti koje zadivljuju svet. Njihova impresivna i fascinantna dostignuća u jednoj, ili više oblasti ljudskog života, motiv su da budu više deo velike slike sveta u kome živimo. Iz tih razloga, u naučnim radovima koji imaju teorijski i empirijski karakter, javljaju se neslaganja, dileme i problemi oko demistifikacije psihološkog koda vrhunskih talenata u različitim naučnim i umetničkim oblastima. Fokus rada su talenti, ili faktori koji određuju njihova „natprirodna postignuća”. Rad nastoji da identifikuje psiho-fizičke karakteristike vrhunskih talenata i njihov prepoznatljiv učinak u različitim oblastima koje nazivamo izuzetnim postignućem ili „ekspertskom” izvrsnošću kompetencija. Cilj je da se identifikuju karakteristične razlike koje karakterišu vrhunske talente iz različitih oblasti i umetnosti (nauka, sport, muzika). U radu je korišćen istraživački metod meta-analize dokumentacije, koji omogućava reprezentativan uvid u najznačajnije performanse vrhunskih talenata. Dobijeni rezultati odražavaju prepoznatljiv psihološki kod koji je jedinstven i svojstven samo onima koji stoje na pijedestalu svetske elite vrhunskih postignuća. Rezultati će biti od posebne koristi za harmonizaciju dalje društvene percepcije talenata, kao i za institucionalni tretman, ali i za samopercepcionu sliku samih talenata, koji su od posebnog značaja za njihovu dalju pedagoško-psihološku, sociološku percepciju emocionalne, didaktičke i druge stimulacije.

Ključne reči: talenti, vrhunski rezultati, psihološki kod, samopercepciona slika.

\section{Uvod}

Nepobitna je činjenica da su ljudski resursi glavni nosioci razvoja civilizacije u svim društvenim epohama. Oni povećavaju svoju vrednost kada se u njima identifikuju njihovi izuzetni fizički, intelektualni, društveni, emocionalni i drugi potencijali i talenti. Talenti tako postaju potencijalni kreatori napretka i pojedinačni predstavnici svakog društva. Zato se može reći da je „,rat za talente počeo, traje, i trajaće” još dugo. Neosporna je realnost (Michaels, Handfield-Jones, \& Axelord, 2001) da postoje tri glavna razloga za „rat talenata”. Prvi se odnosi na prelazak iz industrijskog u informatičko doba, drugi se odnosi na rastuću potrebu za talentima, a treći na povećanu mobilnost ljudskih resursa. Da bi pobedile u „,borbi talenata”, organizacije treba da podignu upravljanje talentima na najviši nivo prioriteta (Lewis \& Heckman, 2006), jer talenti poseduju neiscrpnu unutrašnju motivaciju, inteligenciju, karakter i stavove, veštine, znanja, želje za učenjem i razvojem koji su nedostižni za druge (Beechler \& Woodward, 2009), inače će se kriza talenata nastaviti i u budućnosti (Deloitte, 2010). To je glavni razlog zašto darovite i talentovane u društvu treba podržati svim raspoloživim sredstvima (Persson, 2019). Gore navedeni razlozi su motiv da se fokusiramo na ispitivanje psihološkog koda vrhunskih talenata iz „međunarodnog glasa”. Impresivna (nad)moć talenata u jednoj ili više oblasti inspiracija je i izazov za akademike i laike. 
U literaturi iz oblasti psihologije darovitih i talentovanih, kao i u naučnim krugovima, postoje pretpostavljeni faktori i razlozi koji podstiču čoveka na postizanje vrhunskih rezultata. Ali do sada nije u potpunosti razjašnjeno da li je (ili ne) poznata specifična organizacija i interakcija osobina koje talenat čine „,̌udom”. Najčešće su vrhunski (nacionalni) stručnjaci, virtuozi u jednoj, ili više naučnih oblasti i disciplina - samo „trenutna svetla tačka” društvene percepcije, ali ono što se krije oko njihovog neverovatnog uspeha prava je enigma za svakoga, ponekad $i$ za njih same. Upravo ideja i motiv ovog dela je da se „prodre” u dubinu neverovatnog, gotovo savršenog izraza njihovog talenta, koji postaje planetaran, kome se divi cela civilizacija. U tom pravcu će se teorijski razraditi postojeća empirijska argumentacija koja se odnosi na odnos faktora koji određuju razvoj i postizanje vrhunskih rezultata. Ali ono što najverovatnije možemo reći jeste da nauka nema dobru „predstavu” o njihovoj „emocionalnoj pismenosti, emocionalnoj zrelosti” ili njihovom terminu „emocionalno savršenstvo”, koji koristi Goleman (2020). Ostaje da se prouči njihov interpersonalni izraz, ali još više njihov intrapsihički dizajn koji daje vrhunska dostignuća.

\section{Definisanje pojma talenat}

Pre nego što pređemo na empirijsku argumentaciju za razvoj vrhunskih talenata, kao i na izlaganje njihovih stavova o uticaju faktora koji podstiču vrhunske rezultate i postignuća, definisaćemo pojam talenta. U psihološkom smislu, pojam talenat potiče od grčke reči (grč. talanton, lat. talentum), što je prirodni dar koji se može razviti vežbanjem u sposobnosti da se lako, bezbedno i kvalitetno obavljaju aktivnosti na terenu, a antropološki - talentovan (lat. talentum) je onaj ko je prirodno nadaren (Vujaklija, 1997). Za Ganjea (Gagne, 1985) talenat je potencijal, a talenat govori o (izraženom) talentu u jednoj ili više oblasti intelektualne, senzomotorne, kreativne, socio-emocionalne i druge vrste. On smatra da je talenat urođena sposobnost koja je samo „sirovina”, koju treba postepeno transformisati u (najviše) kompetencije koje on naziva talentom. Šire definicije pojma talenat ukazuju da su to izuzetne sposobnosti i veštine u nekoj oblasti (Piansoongnern, Anurit, \& Bunchapattanasakda, 2008). U organizacionom smislu, talenti su elitna grupa ljudi (Coleman, 2005), dodali bismo, koji imaju (najveći) individualni učinak u nekoj oblasti ili talenat koji poseduje pojedinac, onaj koji ima visoke kompetencije kao manifestaciju dostignuća u datoj oblasti. U svakodnevnom govoru o talentima govori se kao o „velikom potencijalu”, ali taj pojam ne treba poistovećivati sa pojmom talenta, čak i ako je u pitanju visok nivo potencijala ili „ocena sposobnosti” (Heinen \& O'Neill, 2004). Talenat je potencijal koji se može manifestovati kroz rad kao kapacitet i najčešće se povezuje sa visokim dostignućima u jednoj oblasti, ali se može iskazati i visokim dostignućima u nekoliko naučnih oblasti, kao što se može videti kod Gardnerove (H. Gardner); višestruke teorije inteligencije. Kada je reč o definisanju i razumevanju pojma talenat, Friman govori o talentu kao manje merljivom aspektu, posebno u oblasti umetnosti.

\section{Teorijsko-empirijska argumentacija: nalazi o postizanju vrhunskih rezultata talenata}

Falk i saradnici (Falk, Lidor, Lander, \& Lang, 2004) ističu da se vrhunski talenti uglavnom identifikuju mnogo ranije, što posebno utiče na njihov fiziološki, psihološki i socijalni razvoj. Ono što je posebno upečatljivo u stvaranju i izgradnji vrhunskih talenata jeste značaj delovanja roditelja i nastavnika/mentora (Howes, 2000) upravo zbog različitog doživljaja sveta oko sebe i raznolikosti njihovih osećanja. S obzirom na sportsko profilisanje vrhunskih predstavnika u toj oblasti, ukazuje se na individualni značaj morfoloških i motoričkih sposobnosti (Erceg, Milic, Sivric, \& Alujevic Kosta, 2014; Reilli, Bangsbo, \& Franks, 2000). U isto vreme oni su facilitatori za visoke performanse u motoričkim performansama (Erceg et al., 2014, prema: Grujic, 2016). 
Kada je u pitanju učenje u bilo kom smislu i usmerena aktivnost, za talenat sa izuzetnim učinkom karakteristično je „određivanje tempa rada prema sebi”, koji je najčešće iznad ostalih; sposobnost podizanja: od kognitivnih ka motivacionim osobinama. Budući da je, kako smo rekli, iz posedovanih sposobnosti za dominaciju donekle proizašla i specifična motivacija za ostvarivanje tog potencijala, odnosno kod je intelektualno nadarenih jači od koda prosečnih sposobnosti, izraženih različitih oblika motivacije. Za motivaciju je značajna potreba za konceptualnom jasnoćom. Kao što ćemo videti, ovi motivi su jasno vidljivi i kada se intelektualni darovi posmatraju kroz prizmu osobina ličnosti.

U objašnjenju specifičnosti psihološkog kodeksa vrhunskih talenata u različitim oblastima koristićemo Renzulijev (J. Renzulli), koncept u definisanju pojma talenat. Njegov koncept darovitosti predstavljen je kao trokomponentni spoj fundamentalnih psiholoških osobina: visoka opšta intelektualna sposobnost, puna posvećenost zadatku i visok nivo kreativnosti. Pretpostavlja se da su prethodno navedene osobine prisutne na najvišem nivou. Međutim, u ovom delu treba napomenuti da Renzuli ističe kognitivne faktore koji imaju poseban značaj za razvoj darovitosti i talenta. Brojna istraživanja potvrđuju da kombinacija više faktora (genetika i uticaj životne sredine) stvara vrhunske talente posebno u oblasti sporta (Baker, 2001). Ukazuje se (Williams \& Reilly, 2000) da su vrhunski talenti brži i tačniji u prepoznavanju i modifikovanju obrazaca ponašanja, bolje predviđaju akcije od drugih, efikasniji su u traženju i isporuci adekvatnih odgovora. Tako isti autori u nalazima svojih istraživanja ističu snažan osećaj samoefikasnosti talenata kao siguran prediktor visokih performansi, ali daju i sugestije da vrhunski talenti imaju najviši nivo ekstraverzije, a stabilnost se odnosi na njihovu emocionalnu samokontrolu (Cox, 2005). Za autore koji ovaj fenomen posmatraju sa aspekta morala, vrednosti/ciljeva/značenja, svojstva moralne zrelosti pomenuti nalazi posmatraju se kao intelektualna zrelost (Gestsdottir \& Lerner, 2007).

Ono što vrhunske talente razlikuje od drugih je nekonformizam, osećaj da su drugačiji, ponekad otpor autoritetu i tako dalje (Sutherland, 2000). Ali, kao posebna distinkcija koja se odnosi na vrhunske talente, jeste stvaranje nečeg novog u svim domenima njihovog individualnog $\mathrm{i}$ društvenog postojanja i emancipacije. Naročito se kod ovih pojedinaca primećuje prisustvo ili sklonost ka perfekcionizmu kao sklonost ka postizanju (najvećeg) individualnog učinka i sklonost ka nametanju visokih kriterijuma uspešnosti, funkcionisanja po principu „sve ili ništa” i dr. Postoji nekoliko indicija da intelektualno superiorni postavljaju mnogo više „perfekcionističke” standarde (Chan, 2010; Maksic \& Ivasaki, 2009), odnosno imaju sklonost ka visokim postignućima (Csikszentmihalyi, Rathunde, \& Whalen, 1993). Pored prethodnih tvrdnji (Altun \& Yazici, 2013) ističu da perfekcionizam, školska motivacija, stilovi učenja, visoko akademsko postignuće sami po sebi otkrivaju razlike između darovitih i prosečnih. Imajući u vidu njihov način razmišljanja, za isti se može reći da je nelinearan, ali asocijativan sa karakteristikom korišćenja različitih divergentnih oblika mišljenja, sa sopstvenim jedinstvenim načinom mapiranja uma Tonija i Berija Buzana (Buzan, Buzan, 2005). Za neka vrhunska muzička imena (Milenković) se smatra da imaju biološki predisponirane sposobnosti, kao i da su ovi virtuozi rođeni u okolnostima u kojima su od rođenja izloženi muzičkim nadražajima. Ali ne treba zaboraviti da genetskom opredeljenju treba dodati i ogromnu individualnu aktivaciju bez koje nema vrhunskih rezultata.

Vrhunski talenti pokazuju dominantne kognitivne karakteristike, kao što su veštine predviđanja i donošenja odluka (tj. perceptivno-kognitivna ekspertiza; Mann, Williams, Ward, \& Janelle, 2007). Nedavna studija objavljena u Koreji (2003) tvrdi da su talenti najlakše usmereni na uspeh, imaju veću potrebu za postignućem, visoko samopouzdanje, visok stepen kreativnosti, otvoreni za nova iskustva i dr. „Verovanje je za mene najuniverzalnija reč, čak i više od nade”; „Da bi neko ostvario svoje snove, mora istinski da veruje u njih" - N. Đoković. Dominantni 
talenti pokazuju dominantne kognitivne karakteristike, kao što su veštine predviđanja i donošenja odluka (tj. perceptivno-kognitivnu ekspertizu; Mann et al., 2007; Bompa, 2000).

Traženje odgovora na pitanje kako talenat može da se pokrene u akciju sa vrhunskim rezultatima, Sternberg (2003) izdvaja sledeće karakteristike: inteligenciju, kreativnost, mudrost i sintezu (Maksic i Djuricic Bojanovic, 2004). U stvari, srž inteligencije je sposobnost „sagledavanja odnosa koji nisu očigledni” (Horn, 1991; prema: Altaras, 2008). Smatra se da za pokretanje sposobnosti neophodna konsolidacije skupa veština potrebnih za visok nivo postignuća u određenim oblastima (Sternberg, 2001; Heller,1995), a to naglašava da sticanje znanja iz određene oblasti igra ključnu ulogu u razvoju specifičnih kompetencija kada pojedinac postaje stručnjak u određenoj oblasti, ali pri tome ne treba zanemariti ni ličnu i društvenu perspektivu u razvoju darovitosti i talenta (Gojkov Rajic, Stojanovic, Safranj, i Gojkov, 2021).

Autor Minhenskog procesnog modela akcije (Ziegler, 2005, 2008) ograđuje se od tradicionalnog modela razumevanja razlika između darovitosti i talenta. O darovitosti govori kao o prilici da se premosti jaz između aktuelnog repertoara aktivnosti i tzv. stručnog izvođenja, tumačenja ili aktivnosti. Novija istraživanja (Carver, 2004) zasnivaju se na isticanju samoregulacije kao faktora vrhunskog postignuća, koja se posmatra kao proces samokontrole ili samopraćenja sopstvenog napretka u postizanju ciljeva, u smislu ostvarenja postavljenih standard iz ugla ličnosti (Gojkov Rajic, 2020). Drugi autor (Karoly, 1993, prema: Gojkov, 2020), takođe, ističe da je posebna samoregulacija kao proces koji omogućava pojedincu da upravlja svojim aktivnostima, usmerenim ka ciljevima koje sam sebi postavlja tokom vremena i u kontekstu koji je promenljiv, ali važan za postizanje visokih rezultata.

Istraživanja pokazuju da postoje individualne razlike u postizanju talenata vrhunskih rezultata koji su rezultat procesa samoregulacione motivacije koja nije statična dimenzija. $U$ tom pravcu regulacija motiviše (Wolters, 2003, 2011) ulaganje aktivnosti koje podstiču i održavaju talente da istraju u postizanju svojih ciljeva (Gojkov, 2020). Kada je u pitanju emocionalna inteligencija vrhunskih talenata, ne možemo da emocije rade zajedno na adaptivne načine u četiri povezane emocionalne sposobnosti: percepcija emocija, olakšavanje misli, razumevanje emocija i upravljanje emocijama.

\section{Genetska predispozicija + socijalna stimulacija + individualna aktivacija = vrhunska postignuća}

Na početku ćemo pokazati maksimalno poštovanje prema svemu što se kaže o procentualnom odnosu faktora koji određuju pojam talenta. Često se u nalazima istraživanja sreće konstatacija da se vrednost izražena procentima procenjuje u sledećim odnosima: talenat 100\%, a rad samo $1 \%$. Naravno, ova teza je veoma respektabilna, s obzirom na razvoj talenta. Ali pokušaćemo da damo drugačije razumevanje, koje može biti radikalnije, ali, naravno, ima svoj argument.

U teorijskoj i empirijskoj analizi proučavanja kontinuiranog razvoja i uspeha vrhunskih talenata, počećemo objašnjavanjem trofaktorskog modela razvoja talenata sa uticajem genetske determinacije, socijalne stimulacije i individualne aktivacije ličnosti. Najpre je značajan nalaz brojnih istraživanja kojima se konstatuje da ličnost (Larsen \& Buss, 2008) predstavlja skup psihičkih osobina i mehanizama unutar pojedinca koji su organizovani, relativno trajni i koji utiču na interakciju pojedinca i njegovu adaptaciju na okruženje. Time bismo došli do nove, za mnoge - vrlo paradoksalne teze da je vrhunski talenat rezultat sledeće magične formule: genetska predispozicija + društvena stimulacija + individualna aktivacija = vrhunska dostignuća . To bi značilo da se ne može govoriti o delimičnoj, nepotpunoj i fragmentarnoj stimulaciji, razvoju i podršci genetskih (re)dispozicija. Takođe, za drugi faktor koji se zove socijalna 
stimulacija (porodica, škola i drugi agensi socijalizacije) nalazi konstatuju da ne može imati nepotpunu i perifernu funkciju u podršci talentu. Individualna aktivacija pojedinca u postizanju vrhunskih rezultata je treći ravnopravni faktor koji dopunjuje ovu trijadu kombinacija za koji bismo rekli da njihovo odsustvo hendikepira ceo proces razvoja talenata. Stoga bismo dodali da se samo uz maksimalnu interakciju, učešće i stimulaciju svih faktora mogu postići vrhunski rezultati. Ovaj interaktivni skup faktora razvoja talenata funkcioniše gotovo u savršenoj kombinaciji. Time se deminizuje učešće i uticaj konstruktivnih elemenata za izgradnju i postizanje vrhunskih svetskih uspeha koji su potencijalno mogući ukoliko tri prethodno navedena faktora imaju maksimalan kapacitet ili učešće. Čini se da se prema matematičkom modelu genetski potencijal može optimalno razviti ako je $100 \%$ stimulisan, dobije $100 \%$ društvenu stimulaciju i 100\% učešće u individualnoj aktivaciji osobe. Naravno, u ovim pravilima postoje izuzeci gde se u nedostatku jednog ili dva od navedenih faktora (genetsko opredeljenje, socijalna stimulacija) mogu naći vrhunska dostignuća kod pojedinaca u različitim oblastima, ali tada je reč o (a)tipičnim slučajevima u kojima se nadoknađuje rasuđivanje jednog ili oba faktora koji izostaju u trozvučnom sastavu. Ali ni u kom slučaju ne možemo biti svedoci vrhunskih naučnih, umetničkih i drugih dostignuća u odsustvu individualne aktivacije ličnosti i njenih psiholoških atributa iz već poznatih razloga.

\section{Zaključak}

Ako analiziramo psihičke procese i funkcije vrhunskih talenata u procesu izvanrednih dostignuća, doći ćemo do zaključka da su oni na svoj način drugačiji, jedinstveni i prepoznatljivi. Konkretno u procesu perceptivnih karakteristika može se istaći da vrhunski talenti u različitim naučnim oblastima i veštinama sa nevidljivom preciznošću i taktom percipiraju prostor i vreme. Njihova vizuelna superiornost u stvaranju čulnih slika, utisaka i apstrakcija daje poseban pečat njihovim produktivnim i reproduktivnim stilizacijama. $U$ oblasti psihičkih procesa, predstave vrhunskih talenata nisu blede ili uopštene slike stvarnosti, već memorisani angažmani koji su u stalnom dometu individualnog pamćenja. Bifokalnost i multifokalnost vrhunskih talenata su zaista karakteristični elementi i razlike u odnosu na druge pojedince. Voljni procesi su daleko iznad referentnih vrednosti proseka i omeđeni su individualnim fanatizmom. Individualni pečat uspeha talenta leži u njegovoj vizuelizaciji sna u stvarnost. Đoković smatra da ako neko hoće da ostvari svoje snove - mora istinski da u njih veruje. Smatra se da je vera najuniverzalnija reč, čak i više od nade. On vidi stvarnost u snu, jer je san neformatizovan čin, ograničen svim vrstama društvenih iluzija. Za njega je najvažnija sadašnjost, dok su prošlost i budućnost samo fikcije, jer se sve dešava u sadašnjosti i u njoj on gradi svoju istoriju/budućnost.

Talenti vrhunskih dostignuća su enciklopedijski predstavnici; oni prolaze kroz sve faze kroz koje prolaze svi talenti, ali se i dalje svojom individualnom harizmom razlikuju od svih koji se kreću od ideje do brenda, harmoničnog proizvoda porodičnih, sportskih i drugih timova. Vrhunski talenat je najveća inspiracija za sebe u potrazi za uspehom. Njihov ličn način za ulazak u stvaralački prostor je empatija. Njihov nivo empatije je na vrhunskom nivou, čak i na granici preosetljivosti na sve što se dešava okolo. Njihova lična veličina je u njihovoj jednostavnosti koja je izraz ljudske nesavršenosti.

Saželi bismo da su motivi samopotvrđivanja i samoaktualizacije kao najviši lični motivi prema Maslovljevoj (A. Maslow) hijerarhijskoj teoriji samo jedan od glavnih „krivaca”, za uspeh o kome govore generacije. Temperamentne i karakterne osobine talenata koje podstiču potencijalne mehanizme da predstavljaju njihov zadivljujući opus - čine ih jedinstvenim i neponovljivim. Magična formula uspeha u talentima funkcioniše po modelu „,̌̌to teže, to lakše” i znači da se tada uključuje senzor uspeha mobilizacijom svih potencijala. Neka ova vizija profilisanja slavnih među najpoznatijima bude povod za rasprave u funkciji onih kojima 
dugujemo (naj)više zbog njihove neprocenjive materijalne i duhovne proizvodnje u kojoj svakodnevno uživamo.

\section{Literatura:}

Altaras, A. (2008). Savremeni pristupi i konstrukti u psihologiji inteligencije: teorijska i empirijska validacija stanovista o visevrsnim neakademskim inteligencijama. Doktorska disertacija. Filozofski fakultet Univerziteta u Beogradu.

Altun, F., Yazici, H. (2013). Perfectionism, School Motivation, Learning Styles and Academic Achievement of Gifted and Non-Gifted Students. Croatian Journal of Education, 16 (4), 1031-1054.

Baker, J., (2001). Genes and training for athletic performance revisited, 5(2). Retrieved from: https://sportsci.org/jour/0102/jb.htm.

Beechler S., \& Woodward I. C., (2009). The global war for talent. Journal of International, Management, Vol. 15, 273-285.

Bompa, T. (2000). Periodizacija: Teorija i metodika treninga. Zagreb: Hrvatski kosarkaski savez.

Buzan, T., Buzan, B. (2005). Mape uma : briljantno razmišljanje. Beograd: Finesa.

Coleman, A. (2005). Talent: a breed apart? Retrieved March 1, 2013, from: http://www.management-issues.com/2006/8/24/research/talent-a-breedapart-.asp.

Cox, R. (2005). Psihologija sporta: koncepti i primjene. Jastrebarsko: Naklada Slap.

Csikszentmihalyi, M., Rathunde, K., \& Whalen, S. (1993). Talented teenagers: The roots of success and failure. New York: Cambridge University Press.

Carver, C. S. (2004). Self-regulation of action and affect. In: R. F. Baumeister \& K. D. Vohs (Eds.), Handbook of Self-regulation. Research, Theory, and Applications (pp. 13-39). New York: Guilford Press.

Chan, D. W. (2010). Perfectionism among gifted and no gifted students in Hong Kong: The use of the Revised Almost Perfect Scale. Journal for the Education of the Gifted, 34 (1), 6898.

Deloitte (2010).Talent edge 2020: Blueprints for the new normal. Retrieved from: http://www.deloittehumancapital.at/wpcontent/6_Talent_WegweiserKrise.Studie.p df"type="application/pdf".

Erceg, M., Milic, M., Sivric, H., \& Alujevic Kosta, A. (2014). Correlation between Morphological Characteristics and Motor Abilities In Young Croatian Soccer Players. Research In Physical Education, Sport And Health, 3(1), 51-56.

Falk, B., Lidor, R., Lander, Y., \& Lang, B. (2004). Talent identification and early development of elite water-polo players: a 2-year follow-up study. Journal of Sports Sciences. 22, 347355.

Gagne, F. (1985). Giftedness and talent: Reexamining a reexamination of the definitions. Gifted Child Quarterly, 29 (3), 103-112.

Gestsdottir, S. \& Lerner, R.M. (2007). Intentional self-regulation and positive youth development in early adolescence: Findings from the $4-\mathrm{H}$ study of positive youth development. Developmental Psychology, 43(2): 508-521.

Goleman, D. (2020). Emocionalna inteligencija. Beograd: Geopoetika.

Gojkov, G., (2020). Self-regulation of learning in the didactics of the gifted. Second international scientific conference gifted and talented creators of the progress, St. Kliment Ohridski University. Bitola: Bitola Faculty of Education.

Gojkov Rajic, A., Stojanovic, A., Safranj, J., i Gojkov, G. (2021). Motivacione strategije kao faktor uspeha akademski darovitih studenata. Tematski zbornik. Vrsac: Univerzitatea „Aurel Vlacu” Rumunija i Visoka skola strukovnih studija za vaspitace „Mihailo Palov”, Vrsac. 
Gojkov Rajic, A. (2020). Faktori anksioznosti darovitih u ucenju stranog jezika. Second international scientific conference gifted and talented creators of the progress, St. Kliment Ohridski University. Bitola: Bitola Faculty of Education.

Grujic, S., (2016). Modelne karakteristike mladih rukometasa u odnosu na morfoloska i motoricka obelezja, doktorska disertacija. Sremska Mitrovica: Univerzitet Educons.

Horn, Dz. L. (1991). Uspon i pad ljudskih sposobnosti. Psihologija, 3-4, 25-46.

Heller, K. (1995). The role of creativity in explaining giftedness and exceptional achievement, European Journal for High Ability, 6(1), 7-26.

Heinen, J.S., \& O'Neill, C. (2004). Managing talent to maximize performance, Employment Relations Today, 31 (2), 67-82.

Howes, C. (2000), Social-emotional climate in child care, child-teacher relationships and children's second grade peer relations. Social Development, 9 (2), 191-204.

Karoly, P. (1993). Mechanisms of Self-Regulation: A System View. Annual Review of Psychology, 44, 23-52.

Larsen, R. J., \& Buss, D. M. (2008). Psihologija licnosti. Jastrebarsko: Naklada Slap.

Lewis R. E., \& Heckman, R. J. (2006). Talent Management: A Critical Review. Human Resource Management Review, Vol. 16, 139-154.

Mann, D. T. Y., Williams, A. M., Ward, P., \& Janelle, C. M. (2007). Perceptual-cognitive expertise in sport: a meta-analysis. J. Sport Exerc. Psychol. 29, 457-478. doi: 10.1123/jsep.29.4.457.

Maksic, S. \& Ivasaki, K. (2009). Perfectionism of academically gifted primary school students: The case of Japan. Gifted and Talented International, 24 (2), 51-60.

Maksic, S., i Djurisic Bojanovic, M., (2004). Kreativnost, znanje i skolski uspeh. Institut za pedagoska istrazivanja. Beograd: Biblid.

Michaels, E., Handfield-Jones, H., \& Axelord, B. (2001). The Warfor Talent. Harvard Business Press.

Persson, R. (2019). Complexity of Giftedness and Creativity Phenomena - Challenges: an Individual and Society. International Scientific Conference Book of Abstracts. Vrsac: Visoka skola strukovnih studija za vaspitace "Mihailo Palov".

Piansoongnern, O., Anurit, P., \& Bunchapattanasakda, C. (2008). Managing talented employees: a study of leading corporations in Europe. European Journal of Social Sciences, 6(1), 70-90.

Sutherland, K. S. (2000). Promoting positive interactions between teachers and students with emotional/behavioral disorders. Preventing School Failure (110-115), Vol. 44, No. 3.

Sternberg, R. (2001). Giftedness as developing expertise: a theory of the interface between high abilities and achieved excellence. High Ability Studies, 12(2), 159-180.

Sternberg, R. (2003): WICS as a model of giftedness. High Ability Studies, 14(2), 109-138.

Vujaklija, M. (1997). Leksikon stranih reci i izraza. Beograd: Prosveta.

Wolters, C. A. (2003). Regulation of Motivation: Evaluating an Underemphasized Aspect of SelfRegulated Learning. Educational Psychologist, 38(4), 189-205.

Wolters, C.A. (2011). Regulation of motivation: Contextual and social aspects. Teachers College Record, 113(2), 265-283.

Williams, A. M., \& Reilly, T. (2000). Talent identification and development in soccer. J. Sports Sci. 18, 657-667. doi: 10.1080/02640410050120041

Ziegler, A. (2005). The actiotope model of giftedness. In: R. J. Sternberg \& J. E. Davidson (Eds.), Conceptions of giftedness, (pp. 411-436). New York: Cambridge University Press.

Ziegler, A. (2008). Hochbegabung. Munchen: Ernst Reinhardt Verlag. 


\section{Biografske beleške autora:}

Bisera Kostadinovska-Stojčevska rođena 1986. u Bitoli, Severna Makedonija. Vanredni je profesor primenjene lingvistike na Obrazovnom Fakultetu, Bitola, Severna Makedonija. Aktivan je član brojnih nacionalnih i internacionalnih naučnoistraživačkih projekata. Učestvovala je na velikom broju nacionalnih i internacionalnih konferencija. Trenutno je član skupštine Republike Severne Makedonije.

Ljupčo Kevereski rođen je u Ohridu 1959. Predsednik je ICEI - Internacionalnog Centra za emotivnu inteligenciju, nacionalni koordinator Internacionalnog društva za emotivnu inteligenciju - Inc. (ISEI, New York, USA). Doktorske studije završio je 2004. na Univerzitetu u Novom Sadu. Redovni je profesor na nekoliko univerziteta u Severnoj Makedoniji i Sloveniji. Učestvovao je u velikom broju internacionalnih konferencija u oblastima psihologije, darovitosti i emocionalne inteligencije. 